\title{
Jacques de Villamont: the Discourse of a Catholic Moderate
}

Richard KEATLEY

"Il se tire une merveilleuse clarté pour le jugement humain, de la frequentation du monde."

Montaigne, Essais, I, 26

\section{I}

n June of 1588 , a young man from Brittany made his way from his hometown to the provincial capital of Angers. From there he went to Paris, placed "la moitié de (ses) deniers entre les mains d'un banquier" and set off for Italy. He would return 39 months later, having seen all the major Italian cities, followed the coast of Dalmatia to Greece, Turkey and Morea, visited Cephalonia, Candia, Cypress, Jerusalem, Syria and Egypt - a journey of 5658 miles, "sans compter plusieurs petits voyages (...) pour aller voir diverses choses curieuses" (Villamont $320 \mathrm{v}$ ).

The narrative of this journey, Les voyages du seigneur de Villamont, first published in 1595, became a best seller and was arguably the most popular travel narrative of late sixteenth-century France. ' It is easy to see why. The Voyages offered "antiquitez," lists of "choses curieuses," warnings of the "incommoditez" of travel and cultural observations that were not available in the descriptive works of Renaissance cosmographers. Full of practical advice for the future traveler, the Voyages also paint a picture for the armchair traveler, showing the euphoric beauty of the 
Italian countryside, the customs of Muslim sailors and the chaos of the Neapolitan carnaval. Readers of the Voyages, as Villamont points out, would be "excitez et convivez, par les descriptions des belles villes, citez et provinces que je leur mettray devant les yeux, comme en un tableau, en ce present discours" (Ch. 1, 2 v, emphasis mine). The Voyages were also published in a period hungry not only for narratives of "extraordinary travel," but of descriptions of Italy. Villamont's Voyages offered the advantage of being both.

Yet these obvious selling points do not tell the whole story. The Voyages, in their generic hybridism, - alternating between the narration of the voyage and the poiesis of description - are also, as Villamont states, a "discours." They communicate a specific message to the French public. ${ }^{2}$ The purpose of this article is to discuss this discourse using what we already know about the discourse of travel during this period. ${ }^{3}$ If Villamont traveled, as Robert Aulotte has pointed out, "selon le coeur de Montaigne," then we should read the Voyages in relation to, not only the Journal de voyage, but also Montaigne's comments on travel and general approach to knowledge. My modest goal here is to illustrate how Villamont is similar to Montaigne in his creation of a private "memoire," a work "n'ayant aucune fin que domestique et privee" (Montaigne, Essais, "Au Lecteur), that nonetheless communicates a political message.

In that summer of 1588 , Villamont left a nation consumed by civil war. The Wars of Religion had divided France into two violently opposed camps of Catholics and Protestants for some twenty-six years and France was facing its worst crisis since the tragedies of the Saint Bartholemew's Day, 1572. The date of May 22, 1588 (just weeks before Villamont's passing through the capital) is remembered as the "journée de barricades" in which rumors of a "Saint-Barthélemy à l'envers" (i.e. a slaughter of Catholics by Protestants) led to a total shutdown of the French capital. Alarmed at King Henry's dealings with the Protestant King of Navarre, the Parisian crowds erected barriers around the place Maubert, provoking the king's flight from the capital. The Paris Villamont entered in June of 1588 to change money and arrange for letters of recommendation was a capital plagued by uncertainty and devoid of its sovereign king. Yet Villamont says nothing about this. The young, Catholic aristocrat - a man of arms who would later distinguish himself as author/translator of the Guidon des capitaines - passes through the capital to "suivre (son) dessein," leaving his homeland for a long, expensive journey abroad. 
It is only at the end of this journey that we are told of France's problems. Villamont returns to find the situation worse than when he had left. He is confronted with the violence waged "de l'un et de l'autre party" and notes, along with the companions he had met in Turin, that France is more dangerous than the many exotic places he had just finished visiting:

Adonc estans entrez dedans Lyon, eusmes plus de soucy de retourner en nos patries que n'avions eu (comme je croy) d'entreprendre si longs voyages: Car nous n'apprehendions pas tant de passer par les nations estranges, que nous faisions de passer par la nostre mesmes, par ce que toute la France estoit en trouble et remplie de guerres civiles, toutesfois me mettant en hasard d'estre pris ou massacré par les chemins, partys seulet de Lyon, en habit de pauvre paysant, ... (III, $319 \mathrm{v}-320 \mathrm{r}$ )

A nobleman and now distinguished knight of the "ordre de Jérusalem," Villamont is forced to disguise himself as a simple "paysant." His perceived sense of vulnerability and isolation are expressed in the poignantly simple and diminutive adjective "seulet." He seeks what company he can to protect himself and descends the Loire with a group of merchants, buying a horse in order to "eviter les rencontres de plusieurs coureurs qui estoit en la campagne" and riding in the company of a nobleman on his way to war. He cuts through the "fasceuse forest d'Orleans," perhaps in order to avoid the violence of the League-controlled city. Villamont enters his native land, in essence, through a series of subterfuges and disguises, arriving, much like Ulysses, impoverished and alone, lost in a country that seems bent on killing its returning hero.

Returning to Villamont's opening comments, we can see that his travel, trying experiences abroad and the danger confronted on returning home, are not without a purpose. Villamont encourages us to interpret his work in a political sense and to view his spatial maneuverings - his disguises and refusal to take sides in the on-going conflict - as precedents to political action. As Villamont notes in his Preface, the purpose of travel is to develop political experience:

Entre les moyens que les anciens ont recherché pour acquerir la science de regir et gouverner les grands estats et republiques, celuy semble avoir esté le principal et plus certain que l'experience des gouvernements estrangers apporte, pour ce que sur leur modelle on bastit telle forme qu'on veut, prenant des uns et des autres ce qui est bon, et delaissant le contraire: Comme à la vérité c'est la vraye science politique que l'experience, 
et n'y a aucunes regles de philosophie, ou maxime de police si certaines, que celles que nous apprenons par l'exemple d'autruy: Cela se void és livres des plus advisez et sages qui ayent onques escrit. Et certainement l'experience nous a faict cognoistre que ceux qui avoyent beaucoup voyagé, et remarqué avec jugement les façons de vivre des provinces les plus esloignees, estoient beaucoup plus propres au maniement des affaires, que ceux qui s'estoient contentez de vivre en leurs maisons et fueilleter leurs livres, qui ne peuvent si exactement representer les costumes gardees és pays estranges, que la practique qu'un chacun qui y a esté en apprend. A ceste cause Ulisses est recommandé de ce qu'il avoit veu plusieurs et divers pays, et retenu les mœurs des uns et des autres : car ce n'est rien de voir qui ne juge et qui ne retient ce qu'il a veu pour en faire profit : Et aussi changer d'air, non pas esprit, c'est pourmener sans profit. ("Preface au lecteur" a iii r)

In a comparative approach to political science, Villamont states that the art of ruling ("la science de regir et gouverner") can be learned through "l'experience des gouvernements estrangers." The traveler is a political researcher who assists the home government in adopting "ce qui est bon, et delaissant le contraire." Can this desire to look abroad for political solutions to domestic problems, rather than to the ideological systems that had ravaged the country, be interpreted as a sign of impatience with interminable wars and extremist viewpoints?

Like Montaigne, Villamont emphasizes practical knowledge over theory, showing that politics is a question of "practique" acquired "petit à petit." He also uses a vocabulary that indicates an approach to knowledge similar to that of the skeptic Montaigne. There are no rules of philosophy (n'y a aucunes regles de philosophie...") better than those learned through experience and "l'exemple d'autruy." Throughout the above passage, and indeed throughout the Voyages, Villamont moderates his affirmations using expressions such as "il me semble" and "à ce qu'on dict." He avoids making categorical judgments, an approach that is also central to understanding the Essais. In the above passage he expresses skepticism towards book learning and though he casually cites the authority of books ("cela se void és livres des plus advisez et sages qui ayent onques escrit"), he does so only to criticize theoretical and vicarious learning. Villamont strongly underlines the inferiority of those who "s'estoient contentez de vivre en leurs maisons et feuilleter leurs livres." All these statements build a contrast between travelers, who are "plus 
propres au maniement des affaires" and the sedentary, armchair traveler, who sits at home and believes he understands. Villamont, like Montaigne, praises the vita activa over the vita contemplativa.

Another sign that Villamont shares Montaigne's approach to authority can be seen in his use of classical citation. Both classical references contained in the above-cited passage show Villamont's synthetic, selfserving use of classical references. Classical authors are less authorities than pieces of useful evidence or even, as Montaigne would say, ornaments used to support one's argument but not as its logical foundation. Villamont mentions Ulysses, as is to be expected, but reinforces this classical commonplace with a contemporary statement of the need to retain what one learns abroad. ${ }^{5}$ He also quotes Horace, subordinating, even submerging the Roman's words to his own argument. In a rapid aside tacked on as the premise of an afterthought, Villamont adds, "et aussy changer d'air, non pas esprit, c'est pourmener sans profit." In their original context, however, these words read as a cynical rebuke of the futility of travel and an endorsement of the contemplative life of philosophical stasis:

... nam si ratio et prudentia curas

non locus effusi late maris arbiter aufert, caelum, non animum mutant, qui trans mare currunt, (Epist. I, xi, 25-7)

For if 'tis reason and wisdom that take away cares, and not a site commanding a wide expanse of sea, they change their clime, not their mind, who rush across the sea.

Villamont reverses Horace's original meaning, using his words to endorse his own intention to change his "esprit" by traveling abroad. In that Villamont underlines the proper method for altering one's mind - the mark of the wise traveler being his having "remarqué avec jugement" we can assume that Villamont's narrative will be a record of that alteration. Travel will be a record of judicious observation.

Before examining Villamont's narrative of judgment, however, we will look at one other place in which Villamont explicitly discusses the role of the traveler. While the Preface of the Voyages paints a modern, positivistic view of travel as a pedagogical tool, the first pages of Villamont's narrative provide a more traditional and mystical view of the traveler. Here Villamont speaks of a traveler ordained by God to explore the Creation. The author- 
observer, comparable to Ulysses in his political dimension, is here defined as God's preferred creature, a microcosmos whose quest for learning is central to God's reason for creating the universe:

Comme un excellent peintre, lequel voulant representer en son tableau, la description de plusieurs celebres regions et provinces, n'est content d'y avoir naïvement pourtraict les beaux paysages verdoyants, entre-suivis des prairies esmaillees de diverses fleurs, les claires fontaines et ruisseaux environnant de toutes parts: mais tasche aussi par son industrie d'y effigier quelque belle figure d'homme pour le decorer et enrichir. Ainsi ce divin peintre et ouvrier de toute la nature, ayant une puissance infinie, basty ce beau temple et palais celeste, iceluy orné et embelly d'estincellans flambeaux, l'establissant le throsne et siege de sa Majesté divine, ne s'est contenté seulement de cela, ains a voulu ça bas, d'un divin pinceau peindre et tracer un autre monde terrestre, l'escabeau de ses pieds, auquel il a faict paroistre l'excellence de son ouvrage et labeur admirable de ses mains. Et afin qu'il ne manquast rien au comble de perfection de cest ouvrage, il a creé l'homme dedans le pourpris d'iceluy, auquel il a empraint et gravé l'idée et image de sa divine essence: le constituant Roy et Monarque de tout l'univers, pour s'esgayer et pourmener, par toutes les bornes et limites d'iceluy: afin qu'en telles peregrinations et voyages, il vint avec la raison et ratiocination dont il avoit esté doüé de Dieu à rechercher ce qui estoit de beau et rare sous la voulte des cieux. $(1 \mathrm{r}-\mathrm{v})$

Villamont glorifies scientific curiosity by wrapping the researcher-traveler in a cloak of theological purpose. The words "recherche" and "rechercher" appear frequently in Villamont's narrative, which was later published under the title Recherches curieuses des mesures du monde (1625). The idea of a physical search within God's Creation stands in contrast to and yet is intimately related to traditional representations of the pilgrim's progress toward God. Elsewhere Villamont uses an anthropomorphic image of a Deity whose feet are planted in the Earth and whose "throsne" is located in the "beau temple et palais celeste" of the heavens. Man is thus at the center of a divine architecture represented as a series of concentric circles, a hierarchy that allows him to be compared to God. Just as God rules the heavens by "sa Majesté divine," man is "Roy et Monarque de tout l'univers."

Villamont's originality is, however, less dependent on the idea of dominance than on the use of the image of God as a master craftsman. 
Villamont's God is less anxious to rule than to create beauty that may be observed by a sentient, rational creature. Placing "d'estincellans flambeaux" as visual ornaments to the empty skies, God created "un autre monde terrestre" in order to exhibit "l'excellence de son ouvrage." God's motivation is esthetic, followed by an all-too-human need to have his work admired. The Divine "ouvrier" creates in the manner of "un excellent peintre" and is also beset by an artist's desire to have his work admired.

Man is thus the culmination of a series of successive creations that progress from the idealized beauty of the stars to the terrestrial variety that Villamont explores as he travels through Italy and the Holy Land. God created man to assuage his need for a being who could understand the "labeur admirable de ses mains." The terrestrial earth looks on the stars, but is unable to understand their beauty. Man, however, is "empraint" and "gravé" with an image of the "divine essence." Villamont's indictment of the vita contemplativa is thus made on theological as well as practical grounds. God made man, not to contemplate his Greatness in the abstract, but "afin qu'en telles peregrinations et voyages, il vint avec la raison (...) à rechercher ce qui estoit beau et rare sous la voulte des cieux." Man's observation of beauty fulfills this divine purpose.

Villamont's justification of travel is thus made on two levels: the first political and rational, the second theological and spiritual. The first is one that is traditionally associated with scientific progress and the positivistic history of science. The second, far more interesting in its joining of scientific curiosity and Catholic mysticism, reworks a tradition of reveling in the wonders of the creation. ${ }^{6}$ By articulating his theory of the traveler in two separate points in his work, Villamont melds Catholic, mystical tradition with more contemporary descriptions of the traveler as an "antipilgrim" (Polezzi), a move toward rationalist discourse that is at the same time respectful to traditional Catholic values. This syncretism of values is, I believe, central to the political message of reconciliation of Villamont's Voyages.

Throughout the Voyages, as I stated above, Villamont abstains from using judgmental rhetoric. In all his observations, he suspends judgment in order not to distort the facts he records. One particularly telling place this can be seen is in his treatment of religion. Though Villamont is ostensibly engaged in a pilgrimage, his narrative differs from traditional pilgrimage accounts in its neglect of the religious thematic. Religion does not seem to dominate Villamont's desire to learn about and enjoy the variety of the earth. His description of the Holy Land is provided, not for 
the benefit of the religious pilgrim, but for "ceux qui sont curieux de cognoistre ce qui est beau et remarquable en la terre saincte." If anything can be said to be the driving theme of Villamont's narrative, it is his constant search for "les diversitez des choses qui s'opposent de jour à autre à (nos) sens" (I, 1 v).

Villamont writes a narrative that is respectfully devout but not, on the whole, religious. The values of the pilgrim are tempered by the author's interest in rational, scientific and ethical observation. As Villamont departs Venice for Jerusalem he notes that:

... je m'embarquay en une nave, pour faire le voyage de Hierusalem, (...) que je m'estois de long temps proposé de faire, non par obligation ou voeu, ou appetit de vaine gloire, ains seulement pour le singulier desir et affection que j'avois de visiter le sainct lieu où le Sauveur de nos ames a espanché son sang precieux pour la rançon de tous les humains... (II, $98 \mathrm{v}-99 \mathrm{v}$, emphasis mine)

This statement is telling in that Villamont seems to respond to critics who, from Erasmus to Calvin, saw pilgrimage as a superstitious if not idolatrous practice. Villamont expressly denies the most common motivation for going on pilgrimage: the accomplishment of a vow for a received miracle. ${ }^{7}$ Yet the lengthy clause that explains his curiosity also shows his devout respect for Catholic tradition. Villamont is guilty of neither idolatry, nor vainglory, but is pushed by a "singulier desir" to visit and see.

Though Catholic, Villamont can be critical of the Church, or at least of the general debauchery of the papal capital:

$\mathrm{Au}$ surplus c'est une cité fort libre et asseuree pour tous les poltrons, et où l'on est le bien venu quand on y porte de l'argent: car vivez, hantez les putains, jouëz, blasphemez et commettez toutes sortes de pechez, personne ne vous dira rien: m'estant beaucoup esmerveillé comme les putains et courtisanes y sont tant honorees et licentiees de porter robes de toile d'or ou d'argent, et d'autres riches estofes, bien est vray que pour les discerner d'avec les honnestes femmes, le Pape sixte a faict une ordonnance qu'aucune d'elles ne fust si hardie d'aller en coche. (40r-v).

His approach can be described as moderate Christian rationalism. He is critical of superstition, but is generally not overly concerned with theological matters. At the church of Santa Maria Liberatrice in Rome, for example, Villamont notes the existence of a reputed "fosse, où anciennement l'ancien serpent ou le diable habitoit," adding the 
moderating clause "à ce qu'on dict" (36r). He is similarly diffident of claims that Saint Luke painted the portrait of the Mary at Loreto. In many other places, he records claims of miraculous phenomena without expressing his own opinion - noting the existence of a vial of Christ's blood (34v) or the properties of wondrous fountains (35), and so on. Villamont's goal, in sum, is not to challenge the teachings of the Church, nor to confirm miracles, which are treated like many of the other curiosities he sees along the road.

This tendency to put off analysis and simply record data is the basis of modern scientific method. In Villamont's Voyages, it can also be contributed to a stylistic concern for brevity. Yet there is one important instance where Villamont takes considerable time to investigate a site so miraculous that it defies belief. "Nostre Dame de Lorette" as the French call the Santa casa of Loreto, is a place whose history is so extraordinary that Villamont feels obligated to satisfy the reader's curiosity, placing religious belief under the critical eye of the rational observer. He begins by describing the site's physical characteristics in detail:

. . .vingt colonnes cannelees à la Corinthienne, sur lesquelles sont dix Prophetes, et dix Sybilles. D'avantage le marbre est tres-richement gravé à personnages, où sont representez les mysteres de la Nativité de la glorieuse Vierge-Marie, ses espousailles, son Annonciation, Presentation, Visitation et sa mort, puis la Nativité de nostre Seigneur Jesus-Christ, et l'adoration des trois Rois: finalement les transports admirables de la maison, tous faicts et relevez de marbre blanc, tres-precieux. (69r)

This physical precision prepares for the recounting of the site's miraculous history which Villamont also records exactly. The Santa casa underwent several "transports" by angels - from the Holy Land to Dalmatia and again to a first site in Italy - before finally ending up in Loreto. The house where the Virgin Mary "fut nee, engendree et nourrie, et depuis saluee par l'Ange Gabriel, luy annonçant l'incarnation du fils de Dieu, qu'elle conçeut au mesme lieu" (65v) was "l'an mil deux cents nonante et un (...) "arrachee de ses fondemens, (et) fust miraculeusement transportee de nuict par les Anges" (67r). From there it went to "Sclavonie, en lieu nommé Tersalto," but was soon lifted and placed down "au territoire de Ricanaty" in a woods near the sea $(68 \mathrm{v})$. Two subsequent moves occurred, first to "une petite montagne" where it fell into the hands of a pair of litigious brothers, and finally to "le grand chemin de la communauté de la cité de Ricanaty" (68 v-69 r). Villamont provides physical details that 
support this miraculous history: the appearance of the Virgin Mary, her appearance before a skeptical "Prieur de sainct George de Tersalto Alexandre," the priest's inquiries into the past via a team of experts who traveled to the Holy Land "afin de cognoistre la verité du faict" by taking physical measurements of the original site of the Santa casa (69 r-v). Villamont records all this physical evidence for both miraculous transports of the holy house.

What is most surprising in these descriptions of religious sites such as Loreto is Villamont's objectivity and, from a stylistic standpoint, his failure to engage in the rhetoric of wonder that characterized late medieval pilgrimage accounts. Hyperbole, exuberance, an abundance of descriptors designed to overwhelm the reader are completely absent from Villamont's descriptions of religious sites and phenomena. The transport of the holy house by angels, though perhaps miraculous, is not marvelous.

Villamont's investigation into the origins of the Loreto legend is not, however, a sign of impiety, but of reverence for God's works:

Et parce que c'est un lieu sainct et admirable, je m'enquis fort curieusement (y employant tous mes esprits) pour sçavoir le moyen comme elle avoit esté transportee, et en quel temps cela estoit advenu, encore que j'en peusse sçavoir la vérité par divers tableaux escrits en François, Italien, Espagnol, Grec, Latin, Arabe, Hebrieu, Alleman, Anglois, et Flamen, attachez en l'Eglise sur le banc des Penitentiers de chacune desdites nations. Ce neantmoins je m'enquis d'abondant à plusieurs, tant qu'à la fin, $\ldots(66 \mathrm{v})$

Villamont thus conducts his rational inquiry into Loreto, not in spite of its holiness, but because it is a "lieu admirable," making his exploration more a dismantling of wonder than a confirmation of it. Understanding the limits of human reason involves defining these limits in order to understand at what point human reason no longer applies. Villamont therefore investigates "fort curieusement," "d'abondant," confirming "à plusieurs" and using all of his capacities in order to "sçavoir."

All of Villamont's observations - and there are many in his work of over 640 pages - are illustrative of a young man who shows that he has "remarqué avec jugement," a judgment which shows reason and moderation, qualities that would be needed to serve in the newly formed government headed by a converted Protestant King whose greatest need was for politicians able to bring an end to France's "troubles."

Returning to the France of 1595 , the year in which Villamont published the first edition of the Voyages, the Protestant king Henry IV had come to 
power in 1589 and was still at war with the Catholic League. Villamont's native Brittany had become the center of League resistance, while the historic agreement granting religious freedom to Protestants and signed in the Breton capital of Nantes was still three years away. In 1595, Villamont publishes his Voyages, adding to their opening a hint of an offer of service to the King:

... et ay mis par escrit ce que $\mathrm{j}$ 'ay veu et cogneu de singulier et rare par tout où j'ay esté, dont un autre qui sera employe en meilleurs affaires que je ne suis, pourra faire son profit. Ainsi faut-il rendre à nostre patrie ce devoir, si nous ne sommes employez à le servir, pour le moins ne receler ingratement à ceux qu'on y employe les thresors qui sont cachez en nous (a iij, $r-v$, emphasis mine)

Though Villamont claims to have published his work against his will, this hint at underemployment implies a desire to be recognized. But if Villamont was idle in 1595 , he was perhaps less so in 1600 , since the second edition of his Voyages was published (two years after the Edict of Nantes) not as the work of an obscure "gentilhomme du pays de Bretagne," but by the "Seigneur de Villamont, chevalier de l'ordre de Hierusalem, (et) gentilhomme ordinaire de la chambre du Roy." We can only speculate as to the reason for this promotion. Perhaps the beauty of the Voyages was enough, but it would be interesting to know if Villamont actually assisted in the negotiations at Nantes. If this were true, he would have succeeded where Montaigne failed.

\section{Notes}

1. Les voyages du seigneur de Villamont, cheualier de l'Ordre de Hierusalem,gentil-homme du pays de Bretaigne. Diuisez en trois liures . . - plus un abregé de la description de toute la France : et les ordonnances des cheualiers du Sainct Sepulchre de Hierusalem (Paris: Claude de Monstr'œil and Jean Richer, 1595). The edition I cite in this paper, unless otherwise indicated, is the Paris, Claude Monstr'oeil-Jean Richer edition of 1600 . Other editions were published in Paris $(1604,1609)$, Arras $(1598$, $1602,1606)$, Lyon $(1606,1607,1611)$, Rouen $(1607,1608,1610)$ and Liege (1608).

2. Despite their immense popularity in France, Villamont's Voyages were published exclusively in French-speaking cities as listed above.

3. The literature regarding the theory of travel is quite large, see especially Luigi Monga. 
4. The official government of Orléans had retreated to Beaugency, while the League controlled Orléans.

5. This is the commonplace most mentioned by the authors of the ars apodemica and is perhaps their central concern. Jerome Turler, in his The Traveler, recounts the example of a Neapolitan gentleman who sent his son to the Rome "which was not farre of, and (to) there abide a certeyne time. The young gentleman obeying his commandement went thither and afterwarde returned home, still calling upon his kinsman that he might goe a greater journey. But when his kinsman perceyved that hee had taken no profite by that traveill: said unto him, Sonne, you have seen Medowes, Plaines, Valleis, (...) and whatsoever may else be bound within the compasse of the whole world: abide therfore nowe henceforthwarde at home, and content your selfe" Turler 15-16). Kublai Khan makes a similar comment in the French version of the Milione: ". . . et quant il retournoient, (il) ne li savoient autre (chose) dire que ce pour quoi il estoient alé, si les tenoit touz a folz et a nices et leur disoit: 'Je ameroie miex a oïr les nouveles choses et les manieres des diverses contrees que ce pour quoi tu es alez"' (Marco Polo, vol. I, 130).

6. This tradition stands in opposition to the Augustinian-inspired contemptus mundi. Francis, in addition to his asceticism, offered a version of contemplation of God through Nature. Bonaventure's Itinerarium mentis in Deum continued in this tradition, making the creation the first steps of one's ascent toward God.

7. The Protestant Duke of Rohan makes a similar comment at the opening of his Voyage: "Partant de France, ma resolution estoit de faire mon voyage plus long que l'ordinaire curiosité ne m'ordonne: pource que ne me contentant de voir en iceluy le pays, princes et coustumes des Chrestiens, je voulois aller voir l'empire des Turcs: non par superstition, comme la plus part de ceux qui faisant ce voyage, y vont seulement pour voir Hierusalem, mais, (me voyant inutile ne France la paix estant faicte, et mon peu d'aage plus propre à apprendre qu'à servir pour l'heure à sa patrie) pour passer autant de temps à voir la diversité de ces païs et ces peuples-là" (Rohan 1).

\section{Bibliography}

Bonaventure, Saint. The Journey of the Mind to God. Translated by Philotheus Boehner, edited with introduction and notes by Stephen F. Brown. Indianapolis: Hackett, 1993.

Horace. Satires, Epistles and Ars Poetica. 1926. Cambridge and London: Loeb, 2005. 
Laurensen, John Christian. The Politics of Skepticism in the Ancients, Montaigne, Hume and Kant. Leiden, New York, Köln, 1992, 94-144. Monga, Luigi. "Itinéraires," in Montaigne in Italia.

-. See also, Joseph Catin, Discours viatiques, Pierre Bergeron.

-. "A Taxonomy of Renaissance Hodoeporics: A Bibliography of Theoretical Texts on Methodus Apodemica (1500-1700)." Annali d'Italianistica 14 (1996): 645-661.

Montaigne, Michel de. Essais. Pierre Villey (Ed.), Preface V.L. Saulnier. Paris: Presses Universitaires de France, 1924, 1965, 1992.

-. Journal du voyage de Michel de Montaigne en Italie, par la Suisse et l'Allemagne en 1580 et 1581 . Avec des notes par M. de Querlon. A Rome; et se trouve à Paris: Chez le Jay, rue Saint-Jacques, au GrandCorneille, 1774.

Polo, Marco. Le divisement du monde. Geneva: Droz, 2001.

Rohan, Henri Duc de. Voyage du. . faict en l'an 1600 en Italie, Allemaigne, Pays-bas uni, Angleterre et Escosse. . Amsterdam : Louys Elzevier, 1646.

Schaefer, David Lewis. The Political Philosophy of Montaigne. Ithaca and London: Cornell University Press, 1990.

Turler, Jerome. De peregrinatione, et agro neapolitano. Libri II. Scripti ab Hieronymo Turlero. Omnibus peregrinantibus utiles ac necessarii : ac in eorum gratiam nunc in primum editi. Bernard Jobin : Strasbourg, 1574.

-. English translation (cited here), The Traveiler of Jerome Turler, devided into two Bookes (. . .) conteining a notable discourse of the maner, and order of traviling oversea, or into straunge and forrein Countreys. The second comprehending an excellent description of the most delicious Realme of Naples in Italy. (...). London: William How, for Abraham Meale, 1575. Facsimile edition by Denver Baughan. Gainesville, Florida: Scholars' Facsimiles and Reprints, 1951.

Villamont, Jacques de. Les voyages du seigneur de Villamont, cheualier de l'Ordre de Hierusalem,gentil-homme du pays de Bretaigne. Diuisez en trois liures ... plus un abregé de la description de toute la France : et les ordonnances des cheualiers du Sainct Sepulchre de Hierusalem. Paris: Claude de Monstr'œil and Jean Richer,1595; 1596.

- Les Voyages du Seigneur de Villamont de l'ordre de Hierusalem, Gentilhomme ordinaire de la chambre du Roy. Divisez en trois livres, comme il se voit dans la page suivante. Derniere edition reveuë, corrigeee, et cotee par l'autheur. A Paris: Par Claude de Monstr'oeil 
et Jean Richer, 1600 (Cited edition). Other editions: Paris: Claude de Monstr'oeil et Jean Richer,1604; Jean Richer, 1609. Arras: Gilles Bauduyn and Guillaume de la Rivière, 1598, 1602, 1606. Lyon: Lariot, 1606, 1607; S. Rigaud, 1611. Rouen: T. Dare, 1607; Jean Osmont, 1608; Chez Adrian Ouyn, 1610. Liege: Lambert de la Coste, 1608.

- Traité ou instruction pour tirer des armes, de l'excellent scrimeur Hyéronime Calvacabo (3 sic3), bolognois. Avec un Discours pour tirer de l'espée seule, fait par le deffunt Patenostrier, de Rome. Traduit d'italien en françois par le seigneur de Villamont,... Discours excellent de la chasse... par les quatre saisons de l'année, fait et expérimenté par le sieur de Strosse. Rouen: C. Le Villain, 1609, $1610,1617$.

- Le guidon des capitaines, utile et necessaire a toutes personnes, et principalement à ceux qui suivent l'art militaire: avec un excellent traicté pour apprendre à tirer des armes: plus un brief discours pour aller à la chasse. Rouen: C. Le Villain, 1614. 